\title{
An Investigation into the Role of Employer and Management Representatives during Collective Conciliation: Empirical Evidence from Nigeria
}

\author{
Ige, Adejoke Yemisi (PhD) \\ Department of Employment Relations and Human Resource Management, \\ Faculty of Management Sciences, University of Lagos, Akoka, Yaba, Lagos \\ E-mail: igeadejoke@yahoo.com
}

Received: Sep. 4, 2017 Accepted: Oct. 7, $2017 \quad$ Published: January 1, 2018

doi:10.5296/jmr.v10i1.11802ＵRL: https://doi.org/10.5296/jmr.v10i1.11802

\begin{abstract}
The International Labour Organisation describes ADR as a set of processes that comprise of negotiation, conciliation, mediation and arbitration. This description includes a set of approaches to settling disputes, which in practice vary significantly in terms of their nature and use from one institutional context to another. ADR has been analysed by some scholars as a means of bringing workplace justice to more people at lower cost and with greater speed than conventional government channels. Within the context of ADR, conciliation is seen as one of the most common and important forms of dispute resolution. Although there is a rising interest in the extent of and outcomes of conciliation, its nature in some contexts remains underexplored. This study presents empirical evidence collated among employer, management and trade union representatives as well as other stakeholders that have a role to play in collective conciliation in Nigeria. The study is qualitative due to its suitability for generating data and gathering rich and robust information. A total of twenty-three interviews were conducted between May 2015 and March 2016. The findings of this study reveal the impact of the independence and objectivity of ADR institutions while carrying out their responsibilities. It establishes that management and trade union interactions during conciliation are characterised by lack of trust, lack of confidence, fear and anxiety. It demonstrates how the attitude of management during negotiation can be attributed to their perception of the behaviour and demeanour of trade unions and conciliators. Lastly, the study affirms the link between the mind-set and approaches of the actors and highlights its
\end{abstract}




\section{Macrothink

connection to the actions and behaviour of trade union and management representatives during their interactions as evident within the Nigerian context.

Keywords: Exploration, Role, Employer/Management Representatives, Collective Conciliation, Empirical Evidence, Nigeria. 


\section{Introduction}

Academic debates on ADR and conciliation tend to focus on a number of key aspects of conciliation including the contextual and institutional framework that surrounds it (Hawes, 2000; Goodman, 2000) and the personality and role or styles and strategies of conciliators (Dix et al., 2008; Dix and Oxenbridge, 2004). Other studies have reported how the outcomes of conciliation are dependent on the willingness of the parties to engage in negotiation and make compromise (Bond, 2011; Ruhemann, 2010; Dickens, 2000). More recent studies have focused on the attitude of the parties towards each other, the level of their tolerance of the involvement of an independent third party, and how the action of the parties determines the process and outcomes of conciliation (Broughton and Cox, 2012; Heery and Nash, 2011). None of these studies have presented empirical analysis on the nature and process of collective conciliation hence; this article presents a review of empirical studies on ADR and collective conciliation within the Nigerian context. The aim of this study is to identify the specific factors (through empirical studies) that are involved regarding the role of employer and management representatives during negotiations as well as the process and outcomes of ADR and collective conciliation in practice. The study is qualitative in nature and data will be collected with the use of semi-structured interviews and analysed. This paper is divided into seven sections and structured as follows: Section two presents the meaning, nature and practice of ADR and collective conciliation. Section three examines the factors that shape the nature and process of collective conciliation. Section four considers the attitudes and perceptions of the users of collective conciliation. Section five presents the methodology for the study. Interviews were conducted among Zonal Directors, State Controllers, Assistant Directors, Deputy Directors and Chief Labour Officers at the Ministry of Labour as well as Chairman and President of Employers' Associations, Management representatives, Executive Secretary of Employers' Associations; Director, Nigeria Employers' Consultative Association(NECA) and HR Managers who have been involved at one time or another in collective conciliation. Section six presents a reflection on interview excerpts and deliberates on findings presented among respondents on the role of employer/management representatives. In addition, it presents an analysis on the perception of other actors (namely: conciliators and trade unions representatives) about this role during collective conciliation and concludes.

\section{Review of Literature on the Nature and process of ADR and collective conciliation}

Conciliation and arbitration have been available to employers and their trade unions in the United Kingdom (UK) since the 1800s, although these processes were in minimal use until the 1970s. Industrial courts and tribunal systems and industrial action were the preferred methods for resolving workplace-related disputes (Van Gramberg et al., 2016; Saundry et al., 2016; Hann et al., 2016; Teague and Roche, 2012; Baker, 2002; Mistelis, 2001; Gould, 1998). The establishment of the Advisory, Conciliation and Arbitration Service (ACAS) was a key moment in 1975. ACAS was instituted as a publicly-funded independent organisation that performs a wide selection of functions ranging from handling complaints and giving advice to the providing of conciliation and mediation and arbitration services in both the public and private sectors. This non-statutory system of ADR, carried out by ACAS in the UK is not 
influenced by government policies however; its structure and organisation may be modified or changed by state regulations (Dix and Oxenbridge, 2004; Hawes, 2000; Goodman, 2000). The UK system of conciliation and arbitration shares some features with Canada and Japan. In the 1970s, non-adversarial methods of resolving disputes had been successfully incorporated into the civil procedure system made available for collective dispute resolution in these countries (Forsyth and Smart, 2009; Funken, 2003). The state plays a key role in the formulation of legislation that frames the employment relationship through its contractual dimension and specifically, concerning the recognition and integration of ADR as an alternative method for resolving workplace disputes (Forsyth and Smart, 2009; Funken, 2003).

ADR does vary in nature, however, in different contexts. Pretorius (1993) describes the rise of ADR institutions in South Africa. According to Pretorius's (1993) study, the legal institutions of South Africa's apartheid government were viewed with a great deal of suspicion by the majority of the population, who had become frustrated and discouraged with the system of court proceedings because a power tussle had become the underlying factor influencing the activities of the parties. Alternative dispute resolution processes and their institutions were developed in South Africa in the 1980s. The state has since played a key role, as revealed in its attitude towards trade union and management related issues through the restructuring of the labour laws that make it possible for trade unions to engage with management in collective bargaining and alternative dispute resolution. The situation in South Africa demonstrates how contextual factors within the society translate to the workplace. It indicates how workplace related disputes between trade union and management are perceived and the way in which their perception impacts on the end results of resolution (Nupen, 2014; Bhorat et al., 2009).

In Canada, conciliation and mediation are the primary dispute resolution processes available for the resolution of collective disputes. According to the Federal Mediation and Conciliation Service (FMCS) in Canada, conciliation is conducted by conciliation officers or by a conciliation board appointed by the Minister for Labour. Apart from the conciliation and mediation services provided by the FMCS, private mediation services are widespread in Canada because it is a required step for the parties to take before approaching the court for settlement. Meanwhile in Japan, three methods of ADR are commonplace: conciliation, compromise (a combination of litigation and mediation) and arbitration (Funken, 2003). The importance of the neutrality of ADR institutions while carrying out their responsibilities and the ability of the state to provide financial assistance makes it easy for these ADR institutions to effectively provide voluntary and confidential as well as free services. The key point to note from Canada and Japan's ADR method is that conciliation is in operation and the state is responsible for providing the financial assistance needed by the ADR institutions to maintain their neutrality and provide a confidential service to trade unions and management.

\section{Factors that shape the nature and process of collective conciliation}

A range of studies have examined the factors that shape the nature and process of collective conciliation. Goodman's (2000) analysis examined the causes of disputes that are essential 
while shaping the nature and process of collective conciliation. Goodman's (2000) study in the UK identified the causes as: conflict over the terms and conditions of employment, trade union recognition, redundancy, dismissal and discipline, and changes in working practices. Other empirical studies in the UK (see Hale et al., 2012; Heery and Nash, 2011) have examined the sources of requests for collective conciliation, and the findings reveal both employers' and trade unions' requests for conciliation, although a joint request for conciliation is becoming common. The findings from studies by Hale et al. (2012) and Heery and Nash (2011), also in the UK, put forward the idea that there is a rise in the level of awareness and acceptance of collective conciliation in the workplace. Thus, indicating conciliation may in some circumstances provide the platform needed by employers and trade unions to resolve their differences of opinion and continue with negotiations without resorting to litigation (Hale et al., 2012; Heery and Nash, 2011; Goodman, 2000).

The role of conciliators has formed the focus of a significant portion of studies of collective conciliation. Some see the role of conciliators as enabling a voluntary settlement between the disputing parties (Hernándezet al., 2016; Poole, 2016; Dix, 2000; Lewis, 1982). Others maintain that conciliators carry out their role by acting as intermediaries in the exchange of information and ideas and ensuring that the parties maintain open communications with each other by clarifying issues and establishing mutual grounds for settlement (Clarket al., 2012; Dix and Oxenbridge, 2004; Dix, 2000). Still others find that conciliators are involved in identifying likely barriers to progress by dispelling parties' unrealistic expectations. Furthermore, these studies maintain that conciliators consider with the parties the shortcomings of unresolved disputes, and create reassurance that an acceptable solution will be found (Poole, 2016; Cooper et al., 2016; Goodman, 2000; Kessler, 1980; Goodman and Krislov, 1974).

Many studies (see Dix and Oxenbridge, 2004; Dix, 2000) have described the role of conciliators as providing a calm and informal atmosphere and understanding the difficulties that the parties are faced with and having a knowledge and experience of industrial relations. Conciliators may be able to offer suggestions to the parties about possible solutions by using their experience in a variety of ways specifically to build the confidence of the parties in the process and outcomes of conciliation (Hiltrop, 1985; ACAS Annual Report 2013/14; Dickens, 1979). These roles of conciliators have been grouped into three categories: reflexive, informative and substantive (Dix, 2000). Reflexive roles are concerned with responding to the needs of the parties and establishing a positive working relationship, while at the same time giving the conciliator a better insight and understanding of the case (Kressel and Pruitt, $1989 ; 1985)$. As information providers, conciliators are required to clarify the details of the case and to convey factual information to the parties. While acting in this capacity, conciliators are required to address discrepancies in the knowledge of the parties and ensure that both sides are equally aware and informed of the legislative dimensions of their case. Conciliators' substantive involvement allows them to move the parties towards resolving their dispute by exploring the strengths and weaknesses of the case. This substantive influence of the conciliator is a common feature of conciliation that allows the conciliator to 
assess where parties' interest lie and to consider what is achievable within the limit of the law to promote settlement (Pruitt and Carnevale, 1993; Hiltrop, 1985).

Following on from the explanations on the categorisation of the roles of conciliators, Dix (2000) maintains that the style of conciliators (reactive-proactive, message bearer-influences, passive-forceful) can have a significant impact on the process and results of conciliation. Conciliators' ability to initiate a connection with the parties tends to shape the opinion of the parties about the process of conciliation and have an impact on their view about the approach of the conciliator and the results of conciliation. The conciliators' style - message bearing and seeking to influence - relates to the intention of conciliation to provide an open platform for effective communication. This description highlights the duties of the parties and explains the responsibilities of the conciliator during negotiations. Although some conciliators discuss the details of the case and make an effort to influence the decisions of the parties while bearing messages from one party to the other, others simply convey the required information without engaging with the parties. The behaviour of the conciliator during this process can be said to be a reflection of the personality and technique that the conciliator decides to apply at the different stages of the dispute. It suggests the importance of the way in which conciliators present the arguments of each party and how they (the conciliators) strive to gain the confidence of the parties while seeking to influence the effects of negotiations (Dix, 2000).

These different conciliation roles do, it seems, have an impact on the process and outcomes. Conciliators may decide to act their roles out concurrently to fulfil a variety of purposes, particularly as a case progress. The most satisfied service users tend to be those who have experienced more proactive styles of conciliators (Hale, et al., 2012; Dix et al., 2008; ACAS and Ipsos Mori 2006; Dix 2000), which help the parties to rethink their positions on the dispute. In addition to the role of the conciliators, other factors that have a significant impact on the nature and process of end results of conciliation include: the years of experience of the conciliator, the nature of the involvement of the conciliator, and training, level of involvement or participation of the conciliator in the practical settlement of the dispute (Gibbons, 2007; Dix and Oxenbridge, 2004; Molloy et al., 2003).

\section{Attitudes and perceptions of users of collective conciliation}

Several studies have argued that the approach and opinion of the parties about the conciliator and the process of conciliation tend to influence the outcomes of resolutions. For instance, Molloy et al., (2003) claim that conciliation is mostly used by parties in a dispute when they feel that they cannot move forward without assistance (Heery and Nash, 2011; Dawe and Neathey, 2008; Dix and Oxenbridge, 2004). Others maintain that parties opt for conciliation when they fail to agree or when negotiations have broken down and internal dispute machineries have been exhausted (ACAS, 2014; ACAS and Ipsos Mori, 2006; Goodman, 2000). Some studies assert that the use of conciliation is informed by the desire of the parties to obtain independent and unbiased assistance (Dix et al., 2008; Molloy et al., 2003; Dix, 2000), while others affirm that the choice of conciliation is mainly due to its being the next step in the dispute procedure, or because the settlement process requires the parties to 
conciliate before they can proceed to arbitration (ACAS, 2014; Heery and Nash, 2011; ACAS and Ipsos Mori, 2006).

The central point to take note of is the importance of the parties acknowledging their inability to resolve the dispute and their request for third party assistance. Where collective conciliation is not used, this may be attributed to the view that the disputes have not reached a total impasse (Dawe and Neathey, 2008; Molloy et al., 2003). Others affirm that disputing parties do not see what solution conciliators could find that they cannot possibly find themselves (ACAS, 2014; Bond, 2011; ACAS and Ipsos Mori, 2006). Studies assert that disputing parties are of the opinion that it is their job to sort out disputes without bringing in outsiders, hence signifying the parties' perception about the amount of control that conciliators might have over the case and the fact that what might sound reasonable during conciliation might seem very different outside to their members.

The attitude of the parties towards the conciliator and the conciliation process is a crucial factor here. For instance, the use of conciliation could be perceived by some trade unions and management as a sense of personal failure. Others could view the conciliator as an outsider who does not have as much in-depth knowledge about the industry and the peculiarities that exist within the workplace such as the union-management relationship. This description informs the attitude of some trade unions and management representatives who conclude that the role of the conciliator is not important during conciliation (Bond, 2011; Ruhemann, 2010). According to this viewpoint, since the role of the conciliator is limited to facilitating and not making a judgement on the case like arbitrators or judges, then the parties may as well sit back in the comfort of their workplace and proffer solutions to their dispute; especially since the outcome of conciliation needs to be implemented by employers and trade unions and not by the conciliation. This standpoint indicates that the involvement of conciliators in a collective employment dispute tends to undermine the traditional oppositional dynamics of industrial relations (Bond, 2011; Ruhemann, 2010).

The non-use or low use of collective conciliation can be attributed to fear and anxiety. According to studies by Broughton \& Cox (2012) and Heery and Nash (2011), some employers are of the opinion that by involving conciliators in a collective employment dispute it would result in loss of their control of the settlement process and its possible outcome. This demonstrates the importance of adequate information and education of trade unions and management representatives, as well as other stakeholders that have a role to play in collective conciliation. Training and communication tend to eliminate anxieties and worries by providing opportunities for inquiries to be made about the process and expectations at the end of conciliation. They also provide knowledge of the importance of legislation and the impact of this on negotiations and end results. Additionally, training and communication allow the parties to ask questions and make clarifications will erase misinterpretation and shape their perception as actors and determine the results of collective conciliation (Broughton and Cox, 2012; Heery and Nash, 2011).

Studies do confirm the importance of the conciliator alongside a host of other institutional and contextual factors in shaping the process and outcomes For example, an empirical 
investigation by ACAS and Ipsos Mori (2006) into the settlement rate and satisfaction of disputing parties revealed that $44 \%$ of respondents confirm that conciliators' involvement facilitated the rapid resolution of their case or helped them to move closer towards resolving their dispute. Others reveal that customer satisfaction is particularly high in disputes where most of the key issues were resolved or when some progress was made towards resolution (Booth, et al., 2016; Hale, et al., 2012; Dawe and Neathey, 2008; Hiltrop, 1985). Advocates of this view specify that conciliators who proactively seek agreement with disputing parties record a high rate of satisfaction (Hale, et al., 2012; Dawe and Neathey, 2008). Others establish that the conciliator's ability to identify areas of agreement and disagreement while exploring the parties' points of view on the dispute is also usually associated with a high satisfaction rate. More recent studies that examined the impact of collective conciliation on outcome of disputes and timing of assessment reveal that conciliation has assisted in bringing the parties closer together and has also helped them to avoid industrial action and speed up resolution (Hale, et al., 2012; Heery and Nash, 2011; Bond, 2011; Ruhemann, 2010; Dawe and Neathey, 2008). Still others assert that conciliation has impacted positively on the relationship that exists between the parties and improved the result of the resolution. Studies that considered the impact of conciliators' non-intervention in dispute situations confirm that the case would have resulted in the dispute remaining unresolved or being steered towards industrial action or a strike (Hale et al., 2012; Dawe and Neathey, 2008). The important idea to consider is that irrespective of the approach or style that the conciliator decides to adopt during conciliation the principal aim of building a relationship and exploring the parties' points of view on the dispute, then providing a rapid resolution to improve the results is essential for high customer satisfaction rate (Heery and Nash, 2011; Bond, 2011; Ruhemann, 2010).

Effective communication is an important tool for conciliators because at the end of conciliation it is anticipated that the parties understand each other's position and the legislation, and can identify the strengths and weaknesses of their case with a view to making a compromise when necessary for the dispute to be resolved (Meadows, 2007; Molloy et al., 2003). Parties seek the assistance of conciliators when they are apprehensive about the future; as soon as the parties decide to approach conciliation they need to understand the need to de-emphasize the power relationship key features of Collective bargaining and Negotiation $(\mathrm{CB}$ and $\mathrm{N})$. This is because during conciliation the parties are responsible for proposing solutions that will sustain their relationship. Previous studies assert that instead of the parties maintaining entrenched and deeply-rooted positions during discussions their willingness to negotiate and make concessions is essential, because it has the tendency to facilitate a rapid resolution (ACAS, 2014; Hale et al., 2012; Broughton and Cox, 2012; Bond, 2011; Heery and Nash, 2011; Ruhemann, 2010).

\section{Methodology}

This paper is qualitative in nature and the choice of qualitative research is due to its suitability for generating data which enables the researcher to gather rich and robust data which enhances an understanding of the role of the Nigerian state in collective conciliation (Bryman and Bell, 2015; Creswell, 2012; Saunders et al., 2011). Interviews were conducted 
among Zonal Directors, State Controllers, Assistant Directors, Deputy Directors and Chief Labour Officers at the Ministry of Labour as well as Chairman and President of Employers' Associations, Management representatives, Executive Secretary of Employers' Associations; Director, Nigeria Employers' Consultative Association(NECA) and HR Managers who have been involved at one time or another in collective conciliation. In total, twenty-three interviews were conducted between May 2015 and March 2016. This research is supplemented with analysis of state and trade union documentation around collective conciliation in Nigeria.

\section{Empirical evidence and discussion of findings on the role of employer representatives and perception of other actors about this role}

Representatives of employers or management representatives are tasked with the responsibility of creating organisational systems that integrate efficient and satisfactory operations. In order to accomplish this undertaking the task of management representatives can be considered as planning, organising, staffing and leading, controlling and motivating the workforce towards accomplishing their goals. This explanation infers that the ability of management representatives to conduct their activities in an amicable manner during their interactions with employees and trade unions tends to encourage partnership and co-operation and promote productivity. Nevertheless, the recognition of conflict within the employment relationship cannot be over-emphasised. During conflict situations, the main goal of management representatives is to minimise loss and continue with the production of goods and services so as to guarantee the achievement of profitability and growth. During the interviews, a key issue that emerged was the role and action of management during negotiations. Trade union respondents and conciliators mentioned the reluctance of management to engage with trade unions in negotiations. It also cited management's unwillingness to approach the MOL and conciliator for any form of conciliatory assistance during dispute situations. One female conciliator confirmed this view:

often times the employers look for one excuse or the other not to participate....they try to renege or shy away from issues that emerge(Stakeholder 1, conciliator).

Management representatives on the other hand argued that their attitude is influenced by their perception regarding the process and possible reaction of conciliation. According to one management respondent:

Going into conciliation doesn't assure you of certainty in one way or the other...you are not certain what the outcome will be at the end of the day the matter might not be resolved. It is time consuming, it is cumbersome and you are not certain if the matter would be resolve. The conciliator pushes the responsibility of resolving the dispute to both parties (Stakeholder 16, management representative).

The citation illustrates management's hesitance to engage with trade unions in negotiations especially during dispute situations. This observation links with the analysis that was presented earlier in this chapter regarding the ability of conciliators to build trust and confidence of the disputing parties in the process and outcome of conciliation. As mentioned 
earlier in this chapter, empirical evidence has revealed management's lack of trust and confidence in the neutrality and impartiality of the conciliator as well as in the process and results of collective conciliation. This view echoes the result of earlier empirical investigations in this chapter that indicates the opinion of management about the attitude and approach of MOL towards the parties in dispute. This exploration reflects how conciliators lack of professionalism and industry experience impacts on the ability of the parties to build their confidence in the ability of the conciliator and MOL to assist with the promotion of dispute resolution. It describes the manner in which the parties have confidence in the ability of the conciliator to assist with the improvement of fair and impartial results that takes into consideration, the collective interest of the parties and sustain their existing relationship. One conciliator affirmed this view while commenting on the attitude and approach of management towards trade unions as well as the process of collective conciliation when he said:

There are some well-informed management who know from the onset that conciliation is a process. We have management that has paternalistic approach; some have unitary form of reference. The one with unitary form of reference view the other party bringing them for conciliation as if they were taking them to court. In our settings today when you take someone to court you loss the tie of friendship with the person that is the one I tag as unitary form of reference. But there are some management that are well versed in industrial relations. Some have good industrial relation practitioner when it comes to conciliation they accept it as normal process of dispute settlement. In most cases the willingness to settle is there and they appreciate the role conciliators play (Stakeholder 3, conciliator).

Unions on the other hand argued that management tends to perceive trade unions as coming into the organization to establish parallel arrangement that will provoke workers to make demands that could create instability and disruption to production. According to this union respondent:

Most organizations see the union as a body that is coming to increase wage load. They see the union as a body that is coming to ferment troubles and they also see them as a body that comes in as a counter or parallel management. There is no symbiotic or mutual relationship between management and the union if there was proper orientation that notion wouldn't be there it will have been erased totally (Stakeholder 10, trade union representative).

Empirical evidence presented in the quote demonstrates that management's level of understanding of industrial relations tends to impact on their opinion and actions during negotiations with trade unions. It indicates how this reflection shapes the opinion of other stakeholders about the role of management and the way management representatives are willing to relate with them especially during dispute situations. While supporting this point of view a trade union respondent let out his frustration at the insincerity of management during collective conciliation when he said:

The management are not sincere; they have never being sincere in negotiations. And I'm saying this based on empirical facts; because if they are sincere in negotiations why do they renege in agreements earlier reached? Looking at the time wasted to enter into an agreement and knowing fully well that if you renege in that agreement it will affect manpower what will 
be the debate when the issue is brought to the round table? The best way to prevent crisis is to be proactive; so if the management is sincere from the initial they would have been proactive. But for the mere fact that they are not proactive it therefore raises a stance that they have ulterior motives in their discussion and agreement...some will say no that this agreement was agreed and signed under duress (NUPENG 3, trade union representative).

During the interviews the majority of management respondents claim that the attitude of conciliators regarding trade unions tend to influence their actions. This is because; as management representatives, they need to be thoughtful and very cautious during negotiations so as not to be coaxed by conciliators into making erroneous decisions that will have undesirable effects for their organisation. According to this employer respondent:

The MOL sometimes can be very crafty and if you don't take time they can commit you by the time they commit you; you are in trouble. That they are MOL doesn't mean they know it all just that they have authority which you don't have. When they invite you over they will want to have sympathy on the work force and try to convince you in other to make you feel that something needs to be done for the workers. They want to play the role of a good man and a gentle negotiator; they try to convince the employer to do this and that for the workers. But if you allow them cajole you into such; you will be in serious trouble (Stakeholder 18, employer representative).

The finding gives clear descriptions about the way in which the attitude, approach and trustworthiness of management influence the opinions of trade unions about the behaviour of management during negotiations. It demonstrates that it is the lack of confidence in management's attitude by trade unions that informs their lack of trust and confidence in management's behaviour. The attitude of management within the context of conciliation can be linked to the earlier remarks made by management respondents in this chapter. A summation of the extract indicates management's lack of confidence in the attitude and mind-set of the MOL and conciliators towards them. In the opinion of management during this interview it is the attitude of conciliators and trade unions that informs their behaviour especially during dispute situations. In accordance with the analysis a conciliator resonated the disconnect that exist among the parties. This conciliator mentioned the motive for management's lack of trust in the conciliator, process and outcome of conciliation. According to this conciliator:

Yes the level of trust is hardly established. Like I said management has a mind-set about ministry official they feel they always come to reprimand and find faults. So naturally you will be apprehensive they believe the union is coming to harass them. The management thinks since they are the ones running the business and yet the government comes to tell them they are wrong and the union also are imposing a lot on them, nobody cares about them so they see themselves as been victimized. There is disconnect between all the parties involved...trust and confidence needs to be built before conciliation can work (Stakeholder 4, conciliator). 
Management on the other hand argue that their attitude is usually influenced by the actions of conciliators during negotiations. While confirming this view one management respondent said:

Conciliators always have this persuasive power on employers all the time...we employers see this system working only in the interest of the employees and trade unions...when our interest is on ground their\{conciliators\} persuasive power evaporates (Stakeholder 19, employer representative).

A common trend as identified in the course of this investigation is the lack of trust, anxiety and unwillingness of management representatives to discuss with other stakeholders during collective conciliation. It reveals that failure of conciliators to build the trust and confidence of both parties on their independence, objective and neutral position has a serious implication for the process and outcome of collective conciliation. This has the tendency to influence how trade unions and management perceive the process of conciliation and its end results. It demonstrates the mind-set of management that conciliation is commonly used as a platform by trade unions and conciliators to intimidate and oppress management. The explanation shows reasons for management's apprehension during collective conciliation and reveals how these impacts on their reluctance to attain settlement then default on the execution of the end results arrive at conciliation. According to management respondents during the interview, the result of settlement at conciliation does not usually reflect their interest neither does it take into consideration the expectations of their constituents. While considering management's willingness to implement the outcomes of conciliation, a conciliator affirmed that some foreign management representatives adhere to the results of collective conciliation because of the pressure from their trade unions or out of fear of apprehension or arrest. According to him:

There are some management that we are informed have majority of expatriates, the Europeans not the Asians. When they see the point of the law they are ready to comply or abide by it. You can imagine when you start hearing from an employer stating he brought his money from abroad and investing it here gives you employment and food as if that person is not giving in return his own service; some employers fall into this category. Generally, once employers discover they are on the wrong side of the law they are ready to make amends; while some prove difficult: they only succumb due to pressure and power mounted on them by the workers...or fears of industrial arrest this compels them to toe the line (Stakeholder 2, conciliator).

Trade unions on the other hand argue that management's insincerity during negotiations becomes manifest with their unwillingness to implement the effect of negotiations. According to one trade union respondent:

Management is never sincere in negotiations...they default when it comes to implementing the agreement (Stakeholder 10, trade union representative).

The description establishes some of the reasons for management's apprehension during collective conciliation. It reveals how this reluctance impacts on the decision of management 
to reach settlement at conciliation but then defect on the implementation. A trade union respondent described this attitude of management by explaining the principles and ideologies that inform their attitude and actions during their interaction with unions during conciliation. According to this trade union respondent:

The first principle is that management has a responsibility for decisions that lead to the achievement of corporate goals and they don't want to compromise this. Secondly, they want to be seen to make rational decisions that would optimise corporate resources in the most efficient manner. Thirdly, growth and desire of corporate profitability are paramount in their mind (Stakeholder 10, trade union representative).

Conciliators on the other hand argue that the attitude of some management towards trade union representatives during negotiation is offensive and derogatory. According to this conciliator:

Some management belittle the union representative during negotiations because of their rank and status, so we tell them it shouldn't be so, because once you are at the negotiation table you have equal strength and right to negotiate on the issue, so we make them discuss in good faith and build trust in each other (Stakeholder 6, conciliator).

This account demonstrates the need for the parties to identify and understand their responsibilities as well as the role and duties of other stakeholders involved in the processes and outcomes of collective conciliation. It is this understanding that enables each of the parties to appreciate the standpoint of the other parties during negotiations. It also enables the parties to consider the issues in dispute from the standpoint of the other party such that during negotiations the parties are able to identify the key issues in dispute as well as the areas of common interest. The intention of this process is to enable the conciliator and the parties in dispute to consider the main issues in a logical manner by taking into consideration the critical elements required for the success of conciliation which cannot be understood without taking into consideration the elements that inform the collective forms of interactions mentioned in Chapter Two, namely: information-sharing and communication, trade union and management relationship, state legislation and regulations. This study uses these descriptions to increase our understanding of the social process of collective conciliation.

\section{Conclusion}

In conclusion, this paper reveals how the meaning and significance attributed to ADR tends to influence its nature and determine its process as evident in some context. Furthermore, it demonstrates the importance of the role of the state especially in the formulation of legislations that frame the employment relationship, boost the recognition and integration of $\mathrm{ADR}$ as an alternative method for resolving workplace disputes, and its impact on the process of negotiations and end results of resolution. Another key finding that emerge from the analysis presented in this paper is the impact of the independence and objectivity of ADR institutions while carrying out their responsibilities. Empirical evidence establishes that management and trade union interactions during conciliation are characterised by lack of trust and confidence, as well as by fear and anxiety. It shows the way in which management either 
expresses unwillingness and hesitance in approaching conciliators for assistance, or indicates their willingness to implement the result of negotiation at the end of conciliation. The interview citations presented in this paper demonstrate that the attitude of management can be attributed to their perception of the demeanour of trade unions and conciliators during negotiation. This establishes the link that exists between the mind-set and approaches of the actors and its connection to their actions and behaviour during their interactions. It also indicates how all of the above-mentioned factors impact on their relationship and influence the process and outcomes of collective conciliation in practice in Nigeria.

\section{References}

ACAS, \& Ipsos Mori. (2006). Service user's perceptions of Acas' conciliation in Employment Tribunal Cases (2005): Acas Research and Evaluation Section and Ipsos MORI. Ref: 01/06.

ACAS. (2013/14). Advisory Conciliatory Arbitration Service Annual Report and Account, 2013/14.

ACAS. (2014). Measuring the value and impact of the Advisory Conciliatory Arbitration Service; [online] Acas research publications. Available: http://www.acas.org.uk/researchpapers. (13/11/15).

Baker, A. (2002). Access vs Process in Employment Discrimination: Why ADR Suits the US but not the UK. Industrial law journal, 31(2), 113-134. https://doi.org/10.1093/ilj/31.2.113

Bhorat, H., Pauw, K., \& Mncube, L. (2009). Understanding the efficiency and effectiveness of the dispute resolution system in South Africa: An analysis of CCMA Data. Development Policy Research Unit DPRU Working Paper, (09/137). https://doi.org/10.2139/ssrn.2184182

Bond, C. (2011). Trade unions officers' preferences and attitudes towards dispute resolution: A qualitative follow-up study with non-users of Acas collective conciliation; Acas Research Publications. Online Available: http://www.acas.org.uk/researchpapers. Ref09/11. (13/11/15).

Booth, C., Clemence, M., \& Gariban, S. (Ipsos MORI) (2016).Acas Collective Conciliation Evaluation.Acas research [Online] Avablications. Avable: http://www.acas.org.uk/researchpapers. Ref 06/16. (13/11/15).

Broughton, A., \& Cox, A. (2012). Public sector employers' attitudes to use of Acas collective conciliation; Acas Research Publications. [Online] Available: http//www.acas.org.uk/researchpapers. Ref07/12.

Brown, S, Cervenak, C., \& Fairman, D. (1998).Alternative Dispute Resolution Practitioners Guide.Office of Democracy and Governance, Bureau for Democracy, Conflict, and Humanitarian Assistance, US Agency for International Development.

Clark, N., Contrepois, S., \& Jefferys, S. (2012). Collective and individual alternative dispute resolution in France and Britain. The International Journal of Human Resource Management, 23(3), 550-566. https://doi.org/10.1080/09585192.2012.641078 
Cooper, L.J., Bognanno, M.F., \& Befort, S.F. (2016). What's the Relationships Between Labour Arbitrators' Backgrounds and Outcomes of Discipline and Discharge Awards? An Empirical Analysis. ABA Journal of Labour and Employment Law, 31(3), 433.

Dawe, A., \& Neathey, F. (2008). Acas conciliation in collective employment disputes; Acas research publications. online Available:www.acas.org.uk/researchpapers. Ref 05/08. $(13 / 12 / 15)$.

Dickens, L. (1979). Conciliation, mediation, and arbitration in British industrial relations. Industrial relations: A social psychological approach: 289-308.

Dickens, L. (2000). Doing more with less: Acas and individual conciliation. Employment Relations in Britain, 25, 67-91.

Dix, G. (2000). Doing it with style: The work of the ACAS conciliator in individual employment rights cases 'inB. Towers and W. Brown (Eds) Employment Relations in Britain. 25 years of the Advisory, Conciliation and Arbitration Service, Wiley: Blackwell: London.

Dix, G., \& Oxenbridge, S. (2004). Coming to the table with Acas: from conflict to co-operation. Employee Relations, 26(5), 510-530. https://doi.org/10.1108/01425450410550482

Dix, G., Forth, J. A., \& Sisson, K. (2008). Conflict at work: The pattern of disputes in Britain since 1980. Acas.

Forsyth, A., \& Smart, H. (2009). Third party intervention reconsidered: Promoting cooperative workplace relations in the new 'fair work system'. Australian Journal of Labour Law, 22, 117-146.

Funken, K. (2003). Alternative Dispute Resolution in Japan. University of Munich School of Law Working Paper No. 24. https://doi.org/10.2139/ssrn.458001

Gibbons, M. (2007). A Review of Employment Dispute Resolution in Great Britain, Department of Trade and Industry, online Available: http//www.berr.gov.uk/files/file38516.pdf. 15/12/2015.

Goodman, J.F.B., \& Krislov, J. (1974). Conciliation in Industrial Disputes in Great Britain: A Survey of the Attitudes of the Parties. British Journal of Industrial Relations, 12(3), 327-351. https://doi.org/10.1111/j.1467-8543.1974.tb00011.x

Goodman, J. (2000). "After Building bridges and settling differences: collective conciliation and arbitration under ACAS" in Towers, B and Brown, W. (eds), Employment Relations in Britain: twenty-five years Advisory, Conciliation and Arbitration Service, London: Blackwell.

Gould, N. (1998). September.Alternative dispute resolution in the UK construction industry. In 14th Annual ARCOM Conference: 428-437. 
Hale, C. Barrett, G., \& Bryce, A. Ecorys UK. (2012.2011/12). Acas Collective Conciliation Evaluation. Online Available: Acas research publications. Available: http// www.acas.org.uk/researchpapers. Ref 17/12. 15/11.

Hann, D., Nash, D., \& Heery, E. (2016). Workplace conflict resolution in Wales: The unexpected prevalence of alternative dispute resolution. Economic and Industrial Democracy, https://doi.org/10.1177/0143831X16663013

Hawes, W. R. (2000). Setting the pace or running alongside? ACAS and the changing employment relationship. Employment Relations in Britain, 25, 1-30.

Heery, E., \& Nash, D. (2011). Trade Union Officers and Collective Conciliation a Secondary Analysis, ACAS research paper Ref: 10/11.

Hernández, C.A.M., Solís, L.M.C., Fernández, M.A.M., \& Cisneros-Cohernour, E. (2016). Alternative Dispute Settlement Mechanisms: Towards Restorative Justice in Yucatán, Mexico. US-China Education Review, 6(2), 118-124.

Hiltrop, J.M. (1985). Mediator behavior and the settlement of collective bargaining disputes in $\begin{array}{lllll}\text { Britain. Journal of } & \text { Social }\end{array}$ https://doi.org/10.1111/j.1540-4560.1985.tb00856.x

Kessler, S. (1980). The Prevention and Settlement of Collective Labour Disputes in the United Kingdom. Industrial Relations Journal, 11(1), 5-31.

Kressel, K., \& Pruitt, D.G. (1985).Themes in the mediation of social conflict. Journal of Social Issues, 41(2), 179-198. https://doi.org/10.1111/j.1540-4560.1985.tb00862.x

Lewis, P. (1982). The role of ACAS conciliators in unfair dismissal cases. Industrial Relations Journal, 13(3), 50-56. https://doi.org/10.1111/j.1468-2338.1982.tb00414.x

Meadows, P. (2007). A review of the economic impact of employment relations services delivered by ACAS; NIESR.

Mistelis, L.A. (2001). ADR in England and Wales. Am. Rev. Int'l Arb., 12, 167-441.

Molloy, D., Legard, R., \& Lewis, J. (2003). Resolving Collective Disputes at work: User perspectives of Acas collective conciliation service; Acas research publications [Online]. Available: http//www.acas.org.uk/researchpapers. Ref 01/03. 11/11/2015.

Nupen, C. (2014). Mediation and conflict resolution in South and Southern Africa: A personal account of the past 30 years. African Journal on Conflict Resolution, 13(3), 85-114.

Podro, S., \& Suff, R. (2005). Making more of alternative dispute resolution. Advisory, Conciliation and Arbitration Service (ACAS).

Poole, R. (2016). Facilitating systemic outcomes through anti-discrimination conciliation and the role of the conciliator in this quest. Australasian Dispute Resolution Journal, 27(1), 49-57.

Pretorius, P. (1995). Dispute resolution. Journal of the South African Law, 379. 


\section{Macrothink}

Journal of Management Research

ISSN 1941-899X 2018, Vol. 10, No. 1

Pruitt, D.G., \& Carnevale, P.J. (1993). Negotiation in social conflict. Thomson Brooks/Cole Publishing Co.

Ruhemann, C. (2010). Trade Union negotiating officials' use and non-use of Acas conciliation in industrial disputes; Acas research publications. [Online]. Available: http//www.acas.org.uk/researchpapers. Ref 07/10.

Saundry, R., Adam, D., Ashman, I., Forde, C., Wibberley, G., \& Wright, S. (2016). Managing individual conflict in the contemporary British workplace. Acas Research Paper, 02/16.

Teague, P., \& Roche, W. K. (2012). The growing importance of workplace ADR.The International Journal of Human Resource Management, 23(3), 447-458.

Van Gramberg, B., Teicher, J., \& Bamber, G. (2016). Reshaping the Role of the Tribunal as Third Party in Australian Workplace Conflict Resolution. In Reframing Resolution, 237-263. 